\title{
Supplemented native range and subclover pastures improve lambing rates
}

\author{
Martin R. Dally d Milton B. Jones a Edward J. DePeters
}

\begin{abstract}
Grazing ewes on mature subclover pastures shortly before and during the breeding season was as effective as grazing them on native range pastures and supplementing with alfalfa pellets at a rate of 2 pounds per day. Ewes on both kinds of pasture produced $21 \%$ more lambs than ewes grazed on unsupplemented native pastures.
\end{abstract}

The sheep industry has used flushing - increasing the nutrition of ewes shortly before and during the breeding season to increase their lambing rate - for decades. Studies in the early 1930 s demonstrated that flushing range ewes resulted in a 9 to $18 \%$ increase in the number of twin births. Large trials in Australia and New Zealand produced similarly encouraging results. Researchers there divided the flushing phenomenon into two components: the static effect and the dynamic effect. The static effect was the ewe's body weight at conception. The dynamic effect was the weight change that occurred during the flushing period. The New Zealand study reported a 15 to $20 \%$ increase in the number of lambs born and indicated approximately $50 \%$ of the response was due to the dynamic effect The New Zealand data also indicated a $6 \%$ increase in the twinning rate for every corresponding 10 pounds increase in body weight during flushing. There are several factors that govern the amount of increased lambing rate that can be obtained by flushing: the ewe's genetic potential and age, time of breeding season, length of the flushing period, body weight at conception and change in body weight during flushing and breeding.

To expand the productivity of the sheep industry, producers must increase the pounds of lamb weaned per ewe exposed to the ram. The most effective way to increase that figure is to enhance the lambing rate. Lambing rates can be increased by genetic selection and/or crossbreeding. Selecting for multiple births within a flock will increase the lambing rate by approximately $2 \%$ per year. A more efficient way to increase the lambing rate for the commercial producer is to crossbreed with a breed having a high lambing rate. Research on the Finnsheep breed has concluded that infusing 25\% Finnsheep breeding into a flock will result in a corresponding $25 \%$ increase in lambng rate. Lambing rates can also be enhanced by flushing.

Under California range conditions, the sheep breeding season occurs at the time when forage is rapidly declining in nutritive value. Early studies conducted at the Hopland Field Station indicated that the protein in forage samples obtained by esophageal fistulated sheep dropped from 9.5 to $6.9 \%$ between July and September. Another study conducted at the Hopland Field Station indicated that flushing ewes before and during the breeding season can be very beneficial when the protein in native forage falls below the ewe's nutritional requirements.

In earlier work at the Hopland Field Station, pastures of subclover and Hardinggrass mowed before maturing and left in swaths for grazing during the flushing period resulted in a $16.3 \%$ increase in lambs born compared with native pastures. The disadvantage of mowing is the additional labor required and the equipment cost. Since a nonmowed treatment was not included, the advantage of mowing couldn't be determined.

In our study, we compared two flushing systems - a native range supplemented with alfalfa pellets and a dried subclover range - with a control of nonsupplemented native range. Our study did not define the nutritional elements that led to a response or lack of response.

\section{Three treatments}

We randomized by age 650 grade Targhee ewes, approximately 218 head for each of three years (1986, 1987 and 1988) and assigned them to one of six pastures (three treatments replicated twice). The ewes were all 2 to 5 years old, with three or four ages represented in each of the three years. The treatments were as follows: (1) controlgrazing native range only (NR); (2) grazing native range plus supplementation with 2 pounds of alfalfa pellets per day for 16 or 18 days, depending on year, before the rams were introduced and the first 18 days of the breeding season (SNR); and (3) graz- 


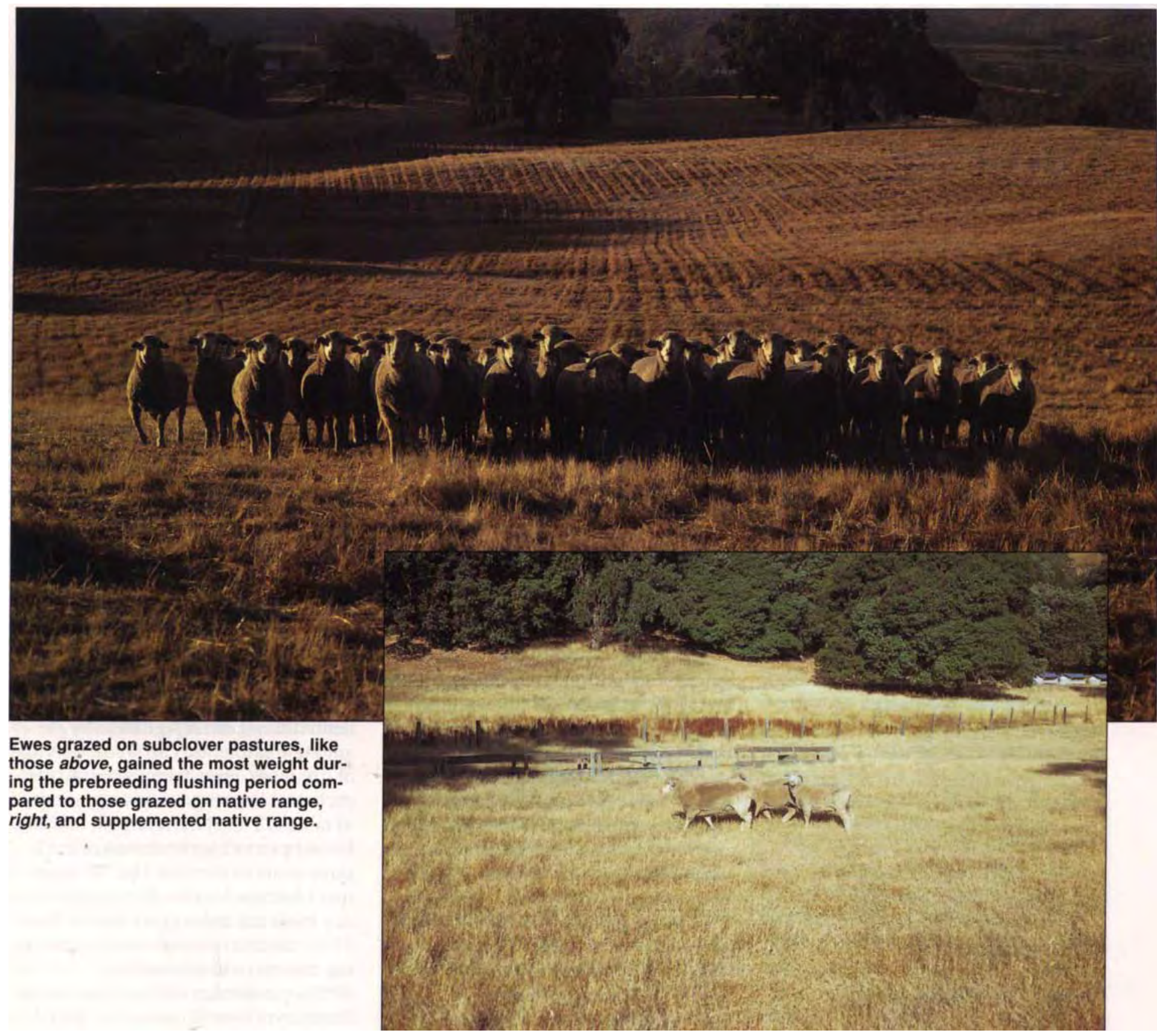

ing dried subclover pastures (SC). Alfalfa pellets had the following nutritive values: crude protein minimum $15.0 \%$, crude fat minimum $1.5 \%$ and ash maximum $12.0 \%$.

Ewes were weighed, given an anthelmintic and vaccinated with vibrio fetus bacterin on June 9 each year. They were then placed in their assigned pasture and allowed to graze the pasture for 16 days before being exposed to rams in 1986 and 1987, and for 18 days in 1988. In all three years of the study, two mature Targhee rams were introduced in each pasture; the approximate ram-to-ewe ratio was $1: 18$, quite a high ratio designed to ensure that all the ewes had an opportunity to be inseminated. Rams were not rotated among treatments during the breeding season. New rams were used each year. All rams were Brucella ovis negative and had passed a service capacity test.

The ewes were reweighed when the rams were introduced. Then at the end of the 32-day breeding season, they were weighed once again and man- aged as a single group until lambing. Ewes were shed-lambed, and the lambing data were recorded as soon as possible after birth.

The SC pastures grazed in this study had been established over 30 years ago and fertilized with sulfur and superphosphate approximately every third year since then. Their predominant subclover cultivar was ' $\mathrm{Mt}$. Barker'. They were grazed at a moderate stocking rate through the winter months each year of the study. Grazing was discontinued on March 15 of 
each year, and then they remained ungrazed until June. The NR pastures were grazed in a similar manner. Alfalfa supplementation was rotated annually among the native pastures. The SNR and NR treatments were alternated between pastures annually in an attempt to remove any individual pasture effect. Table 1 presents the threeyear average plant composition for the three treatments.

\section{Clover and protein levels}

Table 2 presents the average percentage of clover in each kind of pasture over the three years of the trial and the grab sample forage protein percentages for each kind of pasture in 1987 and 1988. Grab sample forage protein levels do not accurately estimate dietary protein levels. Sheep graze selectively, choosing forage that is high in protein; dietary protein levels are therefore routinely higher than protein levels of grab samples.

The low protein levels in 1987 were due, in part, to the very dry spring in 1987, which caused the forage to mature earlier. The percentage of subclover in the SC pastures was lower in 1987 than in 1988,8 and $27 \%$,

\begin{tabular}{|c|c|c|c|}
\hline \multicolumn{4}{|c|}{$\begin{array}{l}\text { TABLE 1. Average plant composition for the } \\
\text { three kinds of pasture, } 1986-1988\end{array}$} \\
\hline \multirow[b]{2}{*}{ Plant species } & \multicolumn{3}{|c|}{ Pasture } \\
\hline & Native & $\begin{array}{l}\text { Supple- } \\
\text { mented } \\
\text { native }\end{array}$ & Subclover \\
\hline Subclover & $<1.0$ & 0.0 & 20.0 \\
\hline Other annual clovers & $<1.0$ & 3.5 & 2.3 \\
\hline Soft chess & 16.0 & 18.0 & 19.0 \\
\hline Wild oats & 24.0 & 17.3 & 5.0 \\
\hline Wild barley & 1.3 & $<1.0$ & 15.7 \\
\hline Medusa & 7.7 & 3.7 & 4.0 \\
\hline Silver hairgrass & 2.3 & 3.3 & 3.0 \\
\hline Filaree & 15.7 & 21.0 & 10.3 \\
\hline Miscellaneous & 30.7 & 32.0 & 20.7 \\
\hline \multicolumn{4}{|c|}{$\begin{array}{l}\text { TABLE 2. Average clover percentage, 1986- } \\
1988 \text {, and percentage forage protein, } 1987 \text { and } \\
1988 \text {, for each pasture type }\end{array}$} \\
\hline \multirow{3}{*}{ Pasture } & \multirow[t]{2}{*}{ Clover } & \multicolumn{2}{|c|}{ Protein } \\
\hline & & 1987 & 1988 \\
\hline & \multicolumn{3}{|c|}{ 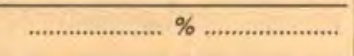 } \\
\hline Native & 1.0 & 7.4 & 8.7 \\
\hline Supplemented native & 3.3 & 7.6 & 10.6 \\
\hline Subclover ${ }^{*}$ & 22.3 & 7.9 & $16.0 t$ \\
\hline
\end{tabular}

respectively. This undoubtedly accounted for the large difference between the levels of protein recorded in those two years in the SC pastures.

The low percentage of clover in the SC pastures in 1987 also had a substantial effect on weight change during the prebreeding flushing period that year. Ewes gained only 2.5 pounds in 1987, compared with 11.5 pounds during 1988.

The greatest variation in plant composition between years occurred in the NR pastures, which averaged $8 \%$ filaree in 1986 , but $24 \%$ in 1988 . During prebreeding, ewes grazing NR pastures lost 2.5 pounds in 1986 , but gained 3.0 pounds in 1988 . Therefore, it is quite clear that the plant composition in a pasture can affect a ewe's ability to gain weight.

\section{Weight gain and lambing rates}

Initial ewe weights, breeding weights and changes in weights are presented in table 3 . Weights within treatments and weight changes for various age groups were analyzed, and since they did not differ significantly, age groups were pooled. Initial body weights among treatment groups were not significantly different, because the ewes had been randomly assigned to treatments. However, breeding weight did differ significantly among the three treatments: The SC ewes were heaviest, followed by the SNR ewes, with the NR ewes the lightest $-143.3,136.2$ and 133.5 pounds, respectively, although the latter two did not differ significantly.

Weight changes during the prebreeding flushing period were greatest for ewes grazing SC pastures. The SNR ewes gained weight during this period, but only $29 \%$ as much as ewes in the SC treatment. Ewes in the NR treatment lost weight during the prebreeding flushing period. At the prebreeding point, the weight changes in the three treatments were all significantly different $(P<0.05)$.

The weight gain differences were also significant at the end of the 51day grazing period (from initial weight to weight at end of breeding season). Ewes grazing SC and SNR pastures gained weight, 12.0 and 4.3 pounds, respectively, whereas ewes grazing the NR treatment continued to lose weight, -3.8 pounds. These results clearly demonstrate the superiority of the SC treatment for body weight gain. However, it should be noted that the SNR treatments were supplemented only for the first 34 days of the 51-day grazing period in 1986 and 1987 and the first 36 days in 1988.

A 10-pound increase in body weight during the flushing period resulted in a $10 \%$ increase in the lambing rate using a simple regression coefficient (b) of lambing rate on weight change.

The percentage of ewes failing to lamb did not differ significantly among treatments. The 3-year average of dry ewes, ewes lambing in the first cycle and lambing rates are presented in table 4. The SNR treatment had the lowest percentage of dry ewes in all three years of the trial; the NR treatment had the highest percentage of dry ewes 2 of the 3 years. Fewer than $5 \%$ of the total ewes were dry, indicating the overall high fertility.

The percentage of ewes conceiving during the first 18 days of the breeding period varied greatly among years. Overall conception rate in the first 18 days was highest in 1986 (79.8\%), compared with $33.3 \%$ in 1987 . Among

\begin{tabular}{|c|c|c|c|c|}
\hline Pasture & $\begin{array}{l}\text { Initial } \\
\text { weight }\end{array}$ & $\begin{array}{l}\text { Breeding } \\
\text { weight }\end{array}$ & $\begin{array}{l}\text { Prebreeding } \\
\text { weight change }\end{array}$ & $\begin{array}{l}\text { Overall weight } \\
\text { change }\end{array}$ \\
\hline & \multicolumn{4}{|c|}{ 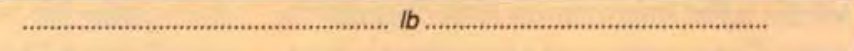 } \\
\hline Native & $134.2 \mathrm{a}$ & $133.5 \mathrm{a}$ & $-0.7 a$ & $-3.8 a$ \\
\hline Supplemented native & $133.7 \mathrm{a}$ & $136.2 \mathrm{a}$ & $2.5 b$ & $4.3 \mathrm{~b}$ \\
\hline Subclover & $134.8 \mathrm{~b}$ & $143.3 \mathrm{~b}$ & $8.5 \mathrm{c}$ & $12.0 \mathrm{c}$ \\
\hline
\end{tabular}


treatments, the ewes grazing SC pastures consistently had the highest first cycle conception rates. However, treatment differences were not statistically significant.

The mean number of lambs born per ewe lambing was significantly improved $(P<0.05)$ for the SNR and SC treatments, compared with the NR treatment. The NR treatment ewes averaged 1.19 lambs, compared with 1.40 lambs for both the SNR and SC ewes. The only year that the SNR treatment had a lower lambing rate than the SC treatment was 1987 (1.26 and 1.34). The lower lambing rate in the SNR treatment that year may be due, in part, to the difference in plant composition in the SNR pastures for that one year. Only $4 \%$ of the plant composition was filaree in 1987, whereas in 1986 and 1988 filaree made up 14 and $45 \%$ of the plant composition, respectively. The percentage of medusa was higher in 1987 than in 1986 and 1988: 15,4 and $4 \%$, respectively. Medusa is a very unpalatable grass and very low in nutritional value.

Lamb birth weights were analyzed by sex and birth type (single or twins), and no significant differences were found among treatments. Average birth weights by year are presented in table 5.

The SC pastures had been fertilized with sulfur. Sulfur fertilization is known to decrease blood selenium levels of animals grazing fertilized pastures. Since selenium deficiency has been documented as a cause of infertility and embryo mortality, in 1986 and 1988 blood samples were collected from 10 randomly selected ewes within each pasture (total 60 ewes) just before the rams were introduced. Blood was sampled from the jugular vein with heparinized syringes and preserved in heparinized containers. A fluorometric procedure was used to determine selenium blood plasma levels. Since all values were above the commonly considered adequate level of $0.05 \mathrm{mg} / \mathrm{ml}$, selenium levels likely had no effect on the ewes' reproductive efficiency. Selenium levels for ewes in the SC, NR and SNR treatments were $0.053,0.055$ and $0.057 \mathrm{mg}$ / $\mathrm{ml}$, respectively.
At the same time selenium blood samples were taken, blood samples were also collected from 18 randomly selected ewes in each treatment to determine blood urea nitrogen (BUN) concentrations. Earlier work conducted at the Hopland Field Station indicated that BUN concentration reflected the nutritional status of the ewe and was highly correlated with lambing rate $(r=0.95)$. Ewes in the SNR treatment had the highest mean BUN level, followed by those in the SC treatment, 14.6 and $11.1 \mathrm{mg} / 100 \mathrm{ml}$ plasma, respectively. As expected, the lowest BUN level was found in ewes in the NR treatment, $7.7 \mathrm{mg} / 100 \mathrm{ml}$. No significant difference was found between the mean BUN for the SNR and SC treatments; however, BUN concentration was significantly higher $(P<0.05)$ for SNR ewes than for NR ewes.

\section{Benefits and relative costs}

Grazing ewes on SC or SNR pastures significantly increased their lambing rate compared to grazing ewes on unsupplemented native range (1.40 lambs compared with 1.19). Ewes grazing SC pasture had significantly higher body weight gains than the SNR ewes, but these weight gains did not result in additional lambs being

\begin{tabular}{|lccc}
\hline \multicolumn{4}{|c}{ TABLE 4. Average lambing performance, } \\
1986-1988
\end{tabular}

'Ewes lambing during first 18 days of lambing season.

Note: Means in each column followed by the same letter do not differ significantly at the $5 \%$ level (Duncan's multiple range test).

TABLE 5. Average lamb birth weight, by year

\begin{tabular}{lccc}
\hline \hline & \multicolumn{3}{c}{ Year } \\
\cline { 2 - 4 } Pasture & 1986 & 1987 & 1988 \\
\hline & $\ldots \ldots \ldots \ldots \ldots .$. & Ib $\ldots \ldots \ldots \ldots \ldots . . .$. \\
Native & 9.2 & 9.9 & 9.4 \\
Supplemented native & 9.8 & 9.9 & 9.3 \\
Subclover & 8.6 & 10.2 & 9.1 \\
\hline
\end{tabular}

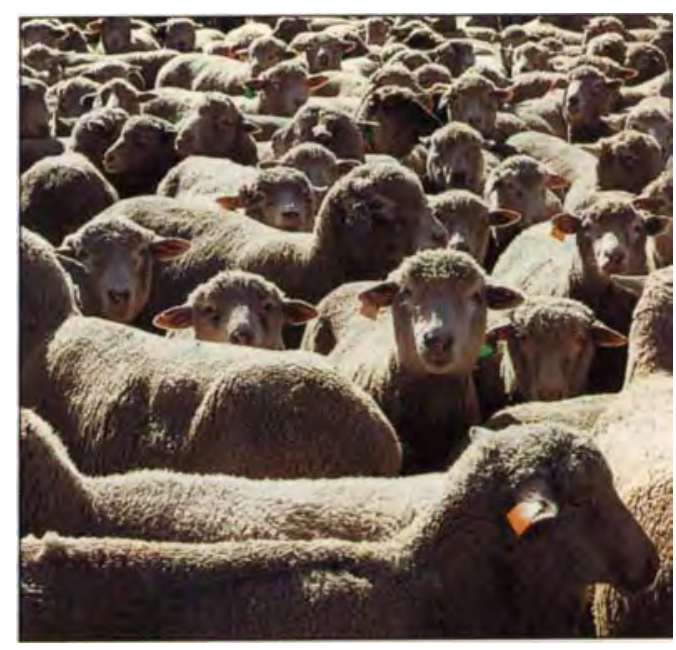

born. They may, however, have resulted in production advantages not investigated in this study, for example, higher fleece weights or increased milk production and greater lamb gains.

The SC treatment costs are the costs of establishing the pasture. The pastures used in this study had been established over 30 years ago, so amortized over 30 years the costs would be quite low. The costs of fertilizing the pastures every third year would also need to be included. However, the increased quality and quantity of forage produced in the subclover pastures before grazing was discontinued on March 15 might pay for both the establishment and fertilizer costs.

The SNR treatment costs per ewe would be $\$ 5.04$ for the pellets, plus the cost of labor to distribute the pellets. This cost is based on alfalfa pellets costing $\$ 140$ a ton and supplementing the ewes for 26 days.

With a flushing cost of $\$ 5.04$, plus labor and a resulting $21 \%$ increase in the number of lambs born, the SNR treatment return on investment would depend on the survival and post-natal growth of the additional lambs born. Other costs related to raising the additional lambs would have to be considererd.

M. R. Dally is Staff Research Associate, Department of Animal Science, Hopland Field Station; M. B. Jones is Agronomist (retired), Department of Agronomy and Range Science, Hopland Field Station; and E. J. DePeters is Associate Professor, Department of Animal Science, UC Davis. 